Harvard Kennedy School Misinformation Review ${ }^{1}$

April 2021, Volume 2, Special Issue on Propaganda Analysis

Creative Commons Attribution 4.0 International (CC BY 4.0)

Reprints and permissions: misinforeview@hks.harvard.edu

DOI: https://doi.org/10.37016/mr-2020-63

Website: misinforeview.hks.harvard.edu

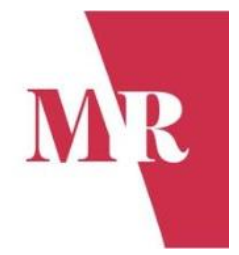

\title{
Propaganda, obviously: How propaganda analysis fixates on the hidden and misses the conspicuous
}

Propaganda analysis has long focused on revealing the rhetorical tricks and hidden special interests behind persuasion campaigns. But what are critics to do when propaganda is obvious? In the late 1930s the Institute for Propaganda Analysis faced this question while investigating the public politicking of $A \& P$, then the largest retailer in the United States. While contemporary critics lambasted A\&P for their secretive campaign, particularly their use of front groups, A\&P used many relatively overt methods of propaganda to win political victories. Propaganda analysis then, as now, fixated on the concealed, failing to adequately critique conspicuous communicative power.

Author: Tim Wood

Affiliation: Department of Communication and Media Studies, Fordham University, USA

How to cite: Wood, T. (2021). Propaganda, obviously: How propaganda analysis fixates on the hidden and misses the conspicuous. Harvard Kennedy School (HKS) Misinformation Review, 2(2).

Received: February 14, 2021. Accepted: March 11, 2021. Published: April 8 ${ }^{\text {th }}, 2021$.

\section{Research question}

- How did the public's misrecognition of propaganda become a defining and enduring problem for the field of propaganda analysis?

\section{Essay summary}

- U.S.-based propaganda analysis has plied exposé as a preferred critical maneuver for almost a century. However, the presumption that audiences are fooled by propaganda mainly because they fail to recognize its provenance, tactics, or intent is an inhibiting conceptual myopia.

- Drawing on archival research, this article examines the retailer A\&P's late-1930s publicity campaign against chain store taxation. Led by the public relations firm of Carl Byoir \& Associates, the campaign used relatively blatant tactics. In fact, Byoir and his contemporaries emphasized the dangers of unseen persuaders and touted their own work as a transparent alternative to that of foreign agents, charlatans, and political provocateurs.

- Propaganda analysis today continues to largely overlook the ways propagandists have co-opted transparency as a strategic tool. Critics must rein in their overreliance on exposé to craft policies and activist practices capable of opposing propaganda in its most overt forms.

\footnotetext{
${ }^{1}$ A publication of the Shorenstein Center for Media, Politics, and Public Policy, at Harvard University, John F. Kennedy School of Government.
} 


\section{Implications}

"We are fooled by propaganda chiefly because we don't recognize it when we see it."

In November 1937 the above sentence opened the monthly pamphlet of the Institute for Propaganda Analysis (IPA), a New York-based organization devoted to exposing the tactics of propagandists. For the ensuing four years this coalition of educators, researchers, journalists, and benefactors provided an institutional home for progressive thinkers to confront issues of mass persuasion (Sproule, 1997, p. 177). The line quoted above was meant to give readers a sense of the fledgling Institute's work but could just as aptly summarize a core analytic framework of the intervening eight decades of propaganda studies. ${ }^{2}$ Whether attending to the rhetoric of texts (Hobbs \& McGee, 2014), psychology of audiences (Jowett \& O'Donnell, 2019), or political-economic contexts of propaganda (Herman \& Chomsky, 1988; Silverstein, 1987), scholars have devoted themselves to uncovering the unseen interests and strategies of persuasive campaigns. This focus is inscribed in the very titles of critical works in this tradition, with accounts of Hidden Persuaders (Packard, 1957), The Unseen Power (Cutlip, 1994), Dark Money (J. Mayer, 2016), and Stealth Communications (Jansen, 2017) resting on the IPA's enduring premise: Propaganda works best when its audiences don't identify it as such.

Exposés of propaganda abide and abound because they have practical value. No audience is immune to misdirection (Davis, 2013, p. 193), thus ferreting out the tactics and hidden interests of persuasive campaigns helps the public evaluate information more lucidly. Furthermore, unveiling covert influence is compatible with a host of aims at the heart of propaganda studies, as revealing opaque persuaders might stoke collective pushes for media ownership reform, new norms of online platform governance, or even strategic counterpropaganda. Exposing hidden propaganda can be a means towards these worthwhile ends.

When it comes to deploying exposé, however, propaganda studies tend to suffer from too much of a good thing. Strenuous attention to the public's misrecognition of propaganda often acts as an inhibiting myopia, one this field of study has proven largely unable to overcome. To illuminate this claim, I turn to the IPA's published exposés, specifically their account of the public relations efforts of The Great Atlantic and Pacific Tea Company, better known as A\&P, in the late 1930s. A\&P, then the largest grocer in the United States, sought to stymie proposed taxes on chain store ownership that would undermine their profitability. Hiring the public relations firm of Carl Byoir \& Associates to head their campaign, the company forged partnerships with unions, farmers associations, consumer movement groups, and a host of other allies (Levinson, 2011). The IPA, in response, published an analysis of A\&P's politicking, seeking to unveil the behind-the-scenes interests backing the campaign.

The problem with the IPA's critique, one often mirrored in today's dominant approaches to the study of propaganda, is that A\&P's work was largely "hidden" in plain sight. The partnerships A\&P forged, the professional communicators they hired, and the persuasive messages they crafted were typically matters of public record. There were elements of misdirection in A\&P's campaign, to be sure, but claims that the public was fooled by A\&P's messaging because they misrecognized the company's propagandistic intent do not hold up to empirical scrutiny.

\footnotetext{
${ }^{2}$ The term "propaganda" carries hefty semantic baggage and has been subject to many competing definitions (L'Etang, 2006). For the purposes of this essay, I use the term in a broad sense, considering propaganda as any large-scale, coordinated public communication effort working towards pre-determined ends or interests. This sense of the term encompasses advertising, public relations, and other communications industries, and thus includes professionals who would likely not define their own work as propagandistic. I consider critical research taking these fields as objects of study to be "propaganda analysis."
} 
This insight is significant because propaganda analysis today continues to fixate on the unseen. This preoccupation shows itself most noticeably in concerns over special interests' appropriation of grassroots political participation. Terms like "front group" and "astroturf organization" are mainstays in critics' lexicons, fastening updated names to strategies common in A\&P's era. While this language offers sharp rhetorical weaponry (R. N. Mayer, 2007), it also presumes that propagandists elicit public support by concealing the interests behind their campaigns. This diagnosis has shaped proposed policy responses to both front groups specifically (Durkee, 2017; Scott, 2019) and misinformation more broadly (Glaeser \& Ujhelyi, 2010), with critics touting tougher disclosure laws for funders of grassroots political organizations. Because critics have diagnosed opacity as a key problem, they frame revelation as the prudent solution.

Just as A\&P's backing of "front groups" was often transparent, however, companies today commonly sponsor citizen advocacy groups openly. If anything, this trend has become more pronounced, with oil companies, ${ }^{3}$ soda makers, ${ }^{4}$ and pharmaceutical giants ${ }^{5}$ candidly mentioning their sponsorship of citizencentered political organizations. Open grassroots advocacy by corporations was a common ad hoc strategy in the era of A\&P; today it is a full-fledged sub-industry (Walker, 2014). Policies demanding greater financial exposure of advocacy will do little to rein in such efforts.

Likewise, unveiling the sources of propagandistic campaigns, even misleading ones, will not inherently lessen their force. Studies show that emphasizing the original source of misinformation online does not dissuade people from sharing or believing the content (Dias, Pennycook, \& Rand, 2020). Research on antivaccine advocates (Ortiz-Sánchez et al., 2020), climate change deniers (Krishna, 2021), and QAnon conspiracy theorists (Zuckerman, 2019) demonstrates that exposing truths is not sufficient to dispel false information.

Clandestine propaganda campaigns do dot the public sphere. The IPA's impulse to raise public awareness of such efforts is one the field of propaganda analysis rightfully continues to cultivate. However, when advocacy campaigns are open about their tactics and finances, they render propaganda studies' longstanding reliance on exposé somewhat moot. Critics and policymakers must also oppose raw forms of institutional power and exercises of propaganda that sit in plain sight.

\section{Findings}

In the late 1930s, A\&P was both flourishing and fragile. While the grocer's low prices had made it the nation's largest retailer, the company raised the ire of small business advocates, who viewed A\&P's economies of scale as a threat to local mom and pop competitors (Levinson, 2011). These criticisms came to a legislative head in 1936 with the passing of the Robinson-Patman Act, ${ }^{6}$ crafted to counter the monopolistic tendencies of chain stores. This legislation was a harbinger of things to come: By late 1938 nineteen states had enacted anti-chain store statutes and U.S. Representative Wright Patman of Texas,

\footnotetext{
${ }^{3}$ Since 2009 the American Petroleum Institute, the largest U.S.-based oil and gas trade group, has run an advocacy organization known as Energy Citizens. While the campaign was relatively tight-lipped about its sponsors initially, the Energy Citizens homepage has for years announced that the campaign is "paid for by the American Petroleum Institute."

${ }^{4}$ Fighting proposed taxes on sugar-laden sodas in San Francisco, California, in 2014, beverage makers sponsored the Coalition for an Affordable City, launching a campaign known variously as Stop Unfair Beverage Taxes and No San Francisco Beverage Tax. The campaign's homepage stated that their actions were "Paid for by the American Beverage Association," the industry's largest trade group.

${ }^{5}$ The Partnership for Safe Medicines is run by a coalition of pharmaceutical interests, including the industry's largest U.S. trade group, the Pharmaceutical Researchers and Manufacturers of America. Ostensibly aimed at combating trade in counterfeit prescription drugs, the group has fought to block importation of inexpensive medications to the U.S. from foreign nations (Kopp $\&$ Bluth, 2018). The organization's website provides a full list of its members.

${ }^{6}$ The bill was proposed as an amendment to the Clayton Anti-Trust Act.
} 
co-sponsor of the earlier bill, was pushing to impose new federal taxes designed to drive large chains out of business (Institute for Propaganda Analysis, 1938, p. 7).

In response, A\&P hired Carl Byoir \& Associates in September 1937 to run a public relations campaign against the proposed taxes. This effort leapt into the public eye in September of 1938 when A\&P financed a nationwide newspaper advertisement laying out the company's position against chain store taxation (Bennett, 1968, p. 203). This publicity drew critical scrutiny to the A\&P's campaign, in particular their formation of third-party advocacy organizations - what would today be called front groups. These groups figured prominently, for instance, in the IPA's analysis of the A\&P campaign, which was mailed to subscribers in December of 1938. The IPA noted that

Mr. Byoir helped to set up the Emergency Consumers Tax Council of New Jersey, an organization representing women shoppers in more than 100 communities. To help it get on its feet, he gave it $\$ 2,000$ of A. \& P.'s money. To keep it there, and feed it with fact and figures, he formed Business Organization, Inc., whose job it will be not only to advise the Tax Council but also to organize similar groups elsewhere. (Institute for Propaganda Analysis, 1938, p. 10)

The IPA did not use the term front group, but their analysis was nonetheless framed as exposé, shining a light on A\&P's sponsorship of citizen-centered advocacy.

Judges and politicians also inveighed against A\&P's front groups. In 1940, U.S. Representative Patman decried A\&P's campaign to Congress, accusing Byoir of founding "dummy organizations" and "propaganda outfits" (86 Cong. Rec. 6951, 1940). ${ }^{7}$ Byoir also faced legal ramifications for his A\&P work, convicted in 1945 under the Sherman Anti-Trust Act of supporting monopolistic practices. The trial judge framed the third-party organizations Byoir founded as ethically dubious, suggesting "the public could not have been and was not aware of the full extent of their sponsorship or the A\&P's responsibility" for the groups. ${ }^{8}$

It is not clear, however, who was fooled by Byoir's efforts, as no empirical evidence of audiences' confusion was offered by the judge or the IPA. More to the point, it does not seem that subterfuge was the campaign's main intention. After all, the advertisement A\&P published to announce their campaign explicitly mentioned the company's hiring of Carl Byoir \& Associates as public relations counsel (The Great Atlantic and Pacific Tea Company, 1938). Furthermore, the ad laid out the company's strategy, avowing A\&P would invest in creating supportive "groups among consumers, farmers and workers." While sponsorship of particular groups was not acknowledged in the ad, A\&P's intention to run a grassroots campaign was unmistakable.

Among the third-party groups Byoir formed, A\&P supported many openly. The two groups named by the IPA provide illustrative examples. Byoir \& Associates announced the creation of the Emergency Consumers Tax Council of New Jersey in a widely circulated press release, with full disclosure of A\&P's status as benefactors. The announcement was picked up by journalists, with newspapers such as the Wall Street Journal covering the story ("A\&P gives \$2,000," 1938); Byoir's role in Business Organization, Inc., created to undertake consumer research for $A \& P$, was less publicized, but was sufficiently well-known to receive laurels in the pages of Public Opinion Quarterly, with the group's links to Byoir and A\&P duly noted (Roat, 1939). While the public at large were unlikely to subscribe to this specialist journal, this evidence

\footnotetext{
${ }^{7}$ Patman, whose legislative agenda repeatedly pit him against A\&P, went much further in his criticism. In the same address Patman claimed that Carl Byoir was "the real brain trust of Nazi propaganda in America," accusing Byoir of using his influence over A\&P to pursue a clandestine fascist agenda (86 Cong. Rec. 6951, 1940). Although Byoir would be fully exonerated of these claims after an FBI investigation, Patman's remarks were covered widely in the press, causing embarrassment to Byoir and A\&P.

${ }^{8}$ The crimes of which Byoir was convicted pertained narrowly to his role in organizing a monopolistic cooperative of agricultural shippers. His founding of purported front groups was not a clear factor in his legal culpability. For an excellent review of the case, see Bennett (1968, pp. 225-277).
} 
suggests the success of the A\&P campaign did not hinge entirely on the company's sponsorship of grassroots groups remaining secret.

To be clear, I am not arguing for the ethical bona fides of A\&P's approach. Their transparency was both partial and strategic. I am suggesting, however, that the A\&P campaign was both generally discernable as propaganda and, by all accounts, succeeded despite this. The IPA's conviction that "we are fooled by propaganda chiefly because we don't recognize it" seems ill-equipped to explain how A\&P's conspicuous campaign earned backers and ultimately won legislative victories.

Why then was the IPA so committed to exposing the A\&P campaign? Why reveal what is already visible? In part, the IPA's work played to public anxieties about propaganda lingering from WWI, which saw even liberal free speech advocates tout increasingly illiberal measures to curb the supposed threat of propaganda (Gary, 1999). By amplifying these anxieties, the IPA fueled interest in their own denunciatory work and aimed to rouse their readers to be vigilant of persuasive campaigns.

The IPA were not alone in stoking fears of hidden persuaders, however. Public relations practitioners used these same anxieties to validate their status as experts. The most infamous self-proclaimed propagandists of the early $20^{\text {th }}$ century such as Carl Byoir, Edward Bernays, and Ivy Lee promoted not only clients, but also their nascent profession, combatting portrayals of public relations as a field "populated by plaid-suited, megaphone-toting hacks [...] or sweet young things who flirted their clients' way onto the news pages" (Zoch, Supa, \& VanTuyll, 2014, p. 723). To do so, they framed their own work as a transparent and rationalized alternative to the pernicious propaganda of foreign agents, charlatans, and others who might have hidden interests. ${ }^{9}$ While Byoir's ilk often failed to meet the standards of openness they extolled, they nonetheless fueled notions that revelation was the solution to the lurking peril of covert influence. While the IPA clamored for exposés of propaganda, Byoir and his contemporaries trumpeted propaganda as exposé.

It is striking that in the early $20^{\text {th }}$ century both public relations' most famous professionals and their harshest critics petitioned with equal fervor for the need to make propaganda recognizable to the public. This unanimity hints at an underlying ideological consensus which, amid the surface-level disagreement of political battles, took exposé as a peerless method of mitigating harmful public persuasion. The core tenet of early propaganda analysis - "we are fooled by propaganda chiefly because we don't recognize it when we see it" - served the very different normative visions of the IPA and public relations practitioners equally well.

The case of the A\&P, then, suggests at least two caveats that ought to accompany propaganda studies' time-honored concern with public misrecognition of propaganda. First, propaganda is often strategically overt, with persuaders using undisguised communication to lend legitimacy to their work. In these instances, critical exposé is of little use. Second, the act of exposé does not necessarily lessen the persuasive force of propaganda, as the public may maintain fealty to either particular propagandists or the ideas they espouse.

Our media environment is a far cry from that navigated by Byoir, A\&P, and the IPA almost a century ago. Thus, studies of networked propaganda have much to show us about the ways transparency is strategically deployed by today's propagandists and the ways audiences respond to contemporary

\footnotetext{
${ }^{9}$ Byoir, for instance, asserted "false propaganda can only temporarily mislead any great number of people and only then when the other side is not fully and adequately presented" (quoted in Bennett, 1968, p. 418); Bernays suggested that while propaganda might be produced "largely by men we have never heard of," the proper response was exposé, the demand that all propaganda be "clearly labeled as to source" (Bernays, 1928/2005, pp. 37, 70); Lee proposed that "the essential evil of propaganda [...] is the failure to disclose the source of the information," waxing poetical to suggest "unseen assassins are dangerous, whether they use stilettos of steel in the dark or seek to poison our minds with falsehoods and half-truths coming we know not whence and aimed at we know not what" (Lee, 1934, pp. 10-11). All three professionals frequently framed their own work as an exercise in transparent public discourse.
} 
persuasion campaigns. The case of the A\&P, however, offers a historical reminder that expose is often a necessary but not sufficient counter to propaganda. Reflecting upon the A\&P campaign ought to prompt those analyzing propaganda today to overcome reliance on revelation, instead crafting policies and activist practices capable of offsetting the obvious communicative power of large companies and other propagandists.

\section{Methods}

This article investigates how public misrecognition of propaganda became a defining and enduring problem for the field of propaganda analysis. The A\&P's late-1930s campaign against chain store taxation provides a useful case study for this exploration for two reasons. First, the contested nature of the campaign demands thinking in relational terms about the power of propagandists and their critics. Too often disciplinary divides coax scholars to study either public relations campaigns or activist advocacy in relative isolation. The direct clash between A\&P and the IPA makes such siloing untenable. Instead, this case prompts us to view public relations as a "socially embedded profession," whose strategies and political efficacy are influenced by other fields of practice (Edwards, 2006, p. 229).

Second, A\&P's campaign against chain store taxation is a particularly productive object of analysis for its notoriety. As Pooley (2008) has argued, the historiography of communications research has often rehearsed Whiggish narratives of the early $20^{\text {th }}$ century's march towards scientistic studies of propaganda. These accounts suppose that the era's research evolved from naïve condemnations of propaganda's unfettered power towards more ostensibly measured empirical approaches. Subsequent scholarship has done much to challenge this portrayal; however, communication studies, even more than other fields, requires fresh appraisals of familiar historical objects. Byoir's work for A\&P is often taken as a watershed moment in cultural and legal considerations of front groups and thus presents an opportune case for rethinking basic presumptions about the power of exposé as a counter to propaganda.

This essay draws from archival records at the New York Historical Society Museum \& Library, including the Henry R. Luce papers; the Wisconsin Historical Society Division of Library, Archives, and Museum Collections, particularly the Gerry Swinehart papers; and New York University's Tamiment Library \& Robert F. Wagner Labor Archives. Historical research always relies on the wisdom of archivists, but I am especially indebted to the staff at each of these institutions. The research for this project was conducted during the COVID-19 pandemic and would not have been possible without their efforts to provide safe access to archival materials.

This project also relied on electronic reproductions of newspapers from ProQuest, including The New York Times, Los Angeles Times, The Washington Post, and The Wall Street Journal. Materials were collected using separate searches for the terms "Byoir," "A\&P," "Emergency Consumers Tax Council of New Jersey," and "Business Organization, Inc."

Research materials were intentionally chosen to scrutinize not only publicly circulated propaganda texts, but also the processes through which propagandists and critics undertook their work. As Logan (2014) argues, professional communicators mobilize dominant ideologies both to craft messages for their clients and to buttress support for their profession. Because of this, public relations is not simply a tactical reservoir for actors with political or economic agendas, but a field that has dramatically shaped the contours of U.S. political discourse as such (Aronczyk \& Espinoza, forthcoming). The archival sources from which my research draws were selected to provide insight into how the rationales, ideologies, and interests of communications practitioners in the late 1930s were inscribed into professional practice. 


\section{Bibliography}

A\&P gives $\$ 2,000$ to aid study of living costs. (1938, August 12). The Wall Street Journal, 4.

Aronczyk, M., \& Espinoza, M. (forthcoming). A strategic nature: Public relations and the politics of American environmentalism. Oxford University Press.

Bennett, R. J. (1968). Carl Byoir: Public relations pioneer (Unpublished master's thesis). University of Wisconsin.

Bernays, E. (2005). Propaganda. IG Publishing. (Original work published 1928)

Cutlip, S. M. (1994). The unseen power: Public relations, a history. Lawrence Erlbaum Associates.

Davis, A. (2013). Promotional cultures: The rise and spread of advertising, public relations, marketing and branding. Polity.

Dias, N., Pennycook, G., \& Rand, D. G. (2020). Emphasizing publishers does not effectively reduce susceptibility to misinformation on social media. Harvard Kennedy School (HKS) Misinformation Review, 1(1). https://doi.org/10.37016/mr-2020-001

Durkee, M. J. (2017). Astroturf activism. Stanford Law Review, 69(1), 201-268.

Edwards, L. (2006). Rethinking power in public relations. Public Relations Review, 32(3), 229-231. https://doi.org/10.1016/j.pubrev.2006.05.013

86 Cong. Rec. 6951 (bound edition, 1940) (statement of Rep. Patman)

Gary, B. (1999). The nervous liberals: Propaganda anxieties from World War I to the Cold War. Columbia University Press.

Glaeser, E. L., \& Ujhelyi, G. (2010). Regulating misinformation. Journal of Public Economics, 94(3-4), 247257. https://doi.org/10.1016/i.jpubeco.2010.01.001

The Great Atlantic and Pacific Tea Company. (1938, September 15). A statement of public policy by The Great Atlantic and Pacific Tea Company [Advertisement]. The New York Times, 52.

Herman, E. S., \& Chomsky, N. (1988). Manufacturing consent: The political economy of the mass media. Pantheon Books.

Hobbs, R., \& McGee, S. (2014). Teaching about propaganda: An examination of the historical roots of media literacy. Journal of Media Literacy Education, 6(2), 56-67. https://doi.org/10.23860/jmle$\underline{2016-06-02-5}$

Institute for Propaganda Analysis. (1938). The A\&P campaign. Propaganda Analysis, 2(3), 7-12. https://archive.org/details/IPAVol2/page/n11/mode/2up

Jansen, S. C. (2017). Stealth communications: The spectacular rise of public relations. Polity Press.

Jowett, G. S., \& O'Donnell, V. (2019). Propaganda and persuasion (7th ed.). SAGE.

Kopp, E., \& Bluth, R. (2017, April 18). Nonprofit working to block drug imports has ties to pharma lobby. NPR. https://www.npr.org/sections/health-shots/2017/04/18/524363014/nonprofit-workingto-block-drug-imports-has-ties-to-pharma-lobby

Krishna, A. (2021). Understanding the differences between climate change deniers and believers' knowledge, media use, and trust in related information sources. Public Relations Review, 47(1). https://doi.org/10.1016/i.pubrev.2020.101986

Lee, I. L. (1934). The problem of international propaganda: A new technique necessary in developing understanding between nations [A private address]. Patricia D. Klingenstein Library at the New York Historical Society.

L'Etang, J. (2006). Public relations and propaganda: Conceptual issues, methodological problems, and public relations discourse. In J. L'Etang \& M. Pieczka (Eds.), Public relations: Critical debates and contemporary practice (pp. 23-40). Lawrence Erlbaum Associates.

Levinson, M. (2011). The great A\&P and the struggle for small business in America. Hill and Wang. 
Logan, N. (2014). Corporate voice and ideology: An alternate approach to understanding public relations history. Public Relations Review, 40(4), 661-668. https://doi.org/10.1016/j.pubrev.2013.12.006

Mayer, J. (2016). Dark money: The hidden history of the billionaires behind the rise of the radical right. Penguin.

Mayer, R. N. (2007). Winning the war of words: The "front group" label in contemporary consumer politics. The Journal of American Culture, 30(1), 96-109.

Ortiz-Sánchez, E., Velando-Soriano, A., Pradas-Hernández, L., Vargas-Román, K., Gómez-Urquiza, J. L., \& Albendín-García, L. (2020). Analysis of the anti-vaccine movement in social networks: A systematic review. International Journal of Environmental Research and Public Health, 17(15), 5394-5415. https://doi.org/10.3390/ijerph17155394

Packard, V. (1957). The hidden persuaders. David McKay.

Pooley, J. (2008). The new history of mass communication research. In D. Park \& J. Pooley (Eds.), The history of media and communication research: Contested memories (pp. 43-69). Peter Lang.

Roat, E. C. (1939). Current trends in public relations. The Public Opinion Quarterly, 3(3), 507-515. https://doi.org/10.1086/265327

Scott, M. J. (2019). Ripping up the astroturf: Regulating deceptive corporate advertising methods. lowa Law Review, 105, 431-461. https://ilr.law.uiowa.edu/print/volume-105-issue-1/ripping-up-theastroturf-regulating-deceptive-corporate-advertising-methods/

Silverstein, B. (1987). Toward a science of propaganda. Political Psychology, 8(1), 49-59. https://doi.org/10.2307/3790986

Sproule, J. M. (1997). Propaganda and democracy: The American experience of media and mass persuasion. Cambridge University Press.

Walker, E. T. (2014). Grassroots for hire: Public affairs consultants in American democracy. Cambridge University Press.

Zoch, L. M., Supa, D. W., \& VanTuyll, D. R. (2014). The portrayal of public relations in the era of Ivy Lee through the lens of The New York Times. Public Relations Review, 40, 723-732. https://doi.org/10.1016/j.pubrev.2014.02.002

Zuckerman, E. (2019). QAnon and the emergence of the unreal. Journal of Design and Science, 6. https://doi.org/10.21428/7808da6b.6b8a82b9 


\section{Funding}

The author received no specific funding for this work.

\section{Competing interests}

The author has no competing interests to declare.

\section{Ethics}

This research did not involve human subjects and thus was not subject to approval from an institutional review board. The use and copyright restrictions of all archived and published materials were followed.

\section{Copyright}

This is an open access article distributed under the terms of the Creative Commons Attribution License, which permits unrestricted use, distribution, and reproduction in any medium, provided that the original author and source are properly credited.

\section{Data availability}

All data was collected from the archives and sources outlined above. For details on data, please contact the author at twood12@fordham.edu. 